\title{
IL21R wt Allele
}

National Cancer Institute

\section{Source}

National Cancer Institute. IL21R wt Allele. NCI Thesaurus. Code C68737.

Human IL21R wild-type allele is located in the vicinity of $16 \mathrm{p} 11$ and is approximately $48 \mathrm{~kb}$ in length. This allele, which encodes interleukin-21 receptor protein, is involved in the regulation of cytokine signaling. A translocation $t(3 ; 7)(q 27 ; p 12)$ that fuses the gene to the BCL6 gene is implicated in diffuse large B-cell lymphomas. 